American Journal of Environmental Sciences 5 (4): 578-587, 2009

ISSN 1553-345X

(C) 2009 Science Publications

\title{
The Groundwater Resources of the Morainic Amphitheatre: A Case Study in Piedmont
}

\author{
Massimo Vincenzo Civita, Marina De Maio and Adriano Fiorucci \\ DITAG-Department of Land Environment and Geo-Engineering, Politecnico di Torino, \\ C. So Duca Degli Abruzzi, 24-10129 Torino, Italy
}

\begin{abstract}
Problem statement: The risk of groundwater pollution and preservation of groundwater quality of these resources are extremely important topics, particularly at the present time in which water is becoming a limitative factor for land development. In this context the main objective of this study was the evaluation of the pollution vulnerability of groundwater in the Ivrea Morainic Amphitheatre (IMA), situated in the North-West of Piemonte. Approach: The case study required the application of the combined approach SINTACS and GNDCI-CNR Basic Method. SINTACS, used only for the evaluation of vulnerability in the plain covered by alluvial materials, was not considered for the hilly area due to lack of sufficient data, necessary to assign values to the seven required SINTACS parameters. Instead the GNDCI-CNR Basic Method was used, based on a survey of hydrogeologic complexes. The hydrogeologic study had identified an unconfined aquifer in the plain area, situated in the fluvial permeable sediments. Moreover the study had identified a confining bed which separates the aquifer from a deep confined aquifer. Analysis of water table aquifer flow patterns and groundwater quality had led to the characterization of some relationships between different aquifers. Results: Vulnerability map showed an important difference between the water table aquifer and the glacial tills aquifers. The first one had a very high vulnerability, due especially to the small depth of middle-high permeable sediments in the water table. The second one, on the contrary, had a low degree of vulnerability. Conclusion: The vulnerability map must be a fundamental component of an overall groundwater protection scheme: Springs in moraines and the confined aquifer in the plain, which was not affected by groundwater contamination, had better characteristics for drinking water designations.
\end{abstract}

Key words: Groundwater pollution, SINTACS, soil

\section{INTRODUCTION}

Groundwater resources are precious assets as a source for drinking water. In fact, compared to surface water resources, they have better quality. For this reason they are subject of increased interest from the science community, together with an increasing realization of their primary importance for human life.

In this context, problems arise to maintain a good balance between water resources availability and their exploitation. Methods to evaluate groundwater vulnerability to contamination are developed and their preservation from pollution is promoted through a more correct and rational land development process and associated human activities.

The hydrgeologic research presented in this study is related to the above mentioned topics and its main goal is to provide a comprehensive characterization of groundwater resources for the area on the left side of the Ivrea Morainic Amphitheatre (Piemonte, Italy). In fact in this area groundwater is the only water resource for the population. Water is drawn with different techniques depending on the different terrain morphology: Directly at the springs in the hilly morainic area and through wells in the unconfined and confined aquifers in the plain.

A particular point of interest for this study has been pollution vulnerability evaluation through the application of the combined approach SINTACS and GNDCI-CNR Basic Method (DLgs. 152/99 Guide Lines APAT, 2001). This approach is particularly useful for border line situations where there are changes in the terrain morphology from plain to hills and mountain areas. Using this approach is also possible to deal with the areas characterized by a lack of hydrogeologic information, as it is the case for the morainic area.

Corresponding Author: Marina De Maio, DITAG-Department of Land Environment and Geo-Engineering, Politecnico di Torino, C. So Duca Degli Abruzzi, 24-10129 Torino, Italy 
The vulnerability map plays a key role in the planning of groundwater usage and preservation and it must be an integral part of an overall groundwater protection scheme.

\section{MATERIALS AND METHODS}

The area is placed in the North-West part of Piemonte, near to the border with Valle d'Aosta. The impressive IMA overlooks the area and represents an evident sign of the glacial Pleistocene activity. The internal plain is crossed by the Dora Baltea River, principal element of the hydrographic network. The study focused on the left side of the Amphitheater, contained between the Dora Baltea River and the left lateral moraine, called "Serra" (Fig. 1).

In addition to the morainic hills, morphological elements that characterize the area are: The bedrock emersion in the Northern part and the Viverone Lake, which drains the surface portion of the unconfined aquifer, as showed in the study of the water table aquifer motion.

Outcrops cover a long geologic period: From the Palaeozoic and Mesozoic era (bedrock), to the Cenozoic era (Pliocene deposits probably linked with the presence of an ancient marine environment), until the latest periods Pleistocene (morainic deposits) and Holocene (alluvial deposits) of the Neozoic era.
Hydrogeology: The analysis of the underground geological structure has permitted to identify the aquifers and to distinguish between deep and superficial water resources. The latter is a fundamental aspect in the exploitation of ground water and in the application of the LR n.22/1996 law.

The general structure includes an unconfined aquifer in the fluvial deposits, which have an average thickness of $30-40 \mathrm{~m}$. This alluvial formation is followed by a thick confining layer made of thin materials, connected to interglacial phases when morainic circles caused an obstruction to water downflowing, thus allowing the formation of basins where clay and silt sedimentation took place.

At the Valle d'Aosta border, where fluvial dynamic has more energy, deposition of coarser materials has occurred. On the other hand when the southwards river slope reduces and the river course becomes winding, transport capacity diminishes and sand and silt sedimentation is favored.

Morainic deposits, instead, are very heterogeneous. From a hydrogeologic point of view any subdivision between the different morainic circles has not been made, as it was impossible to identify distinct aquifers, because of the chaotic mixture of the materials and the lack of hydrogeologic information.

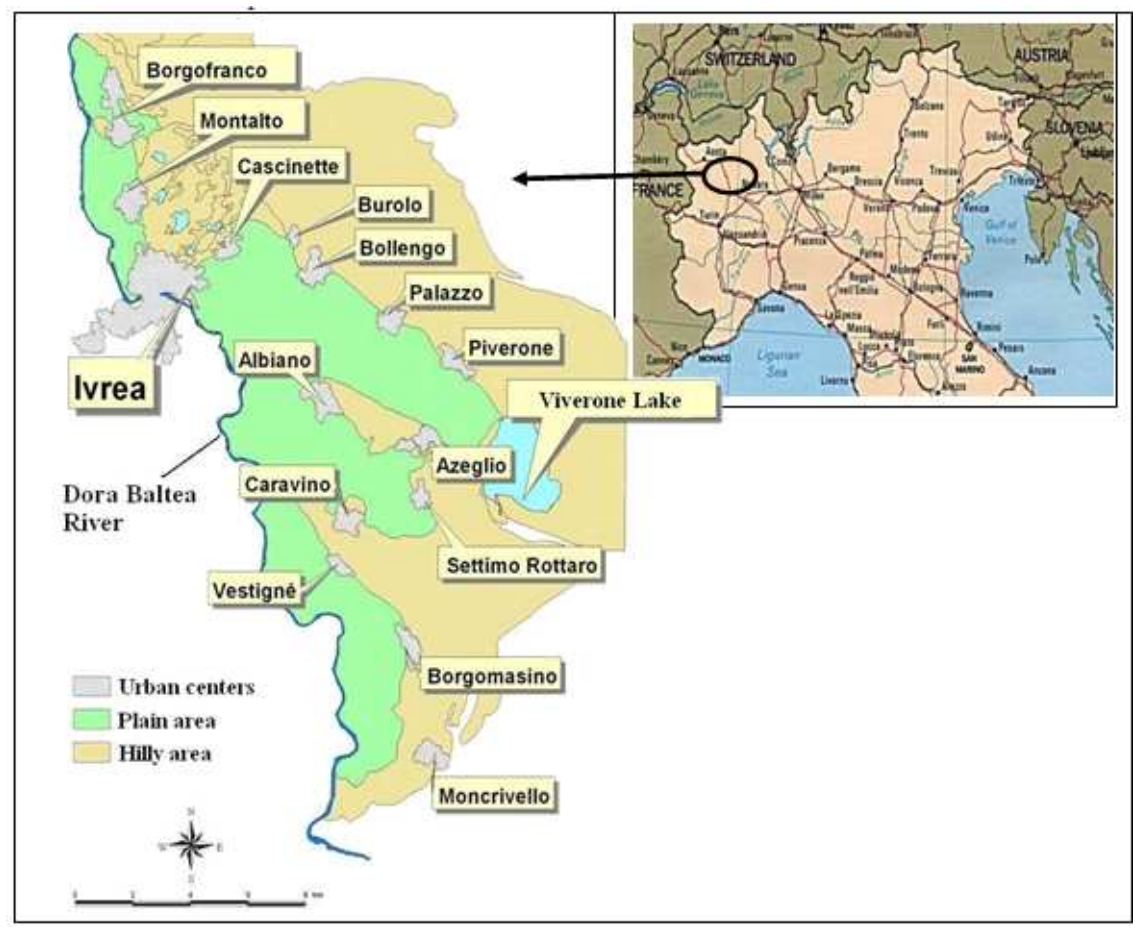

Fig. 1: Geographic place 
Am. J. Environ. Sci., 5 (4): 578-587, 2009

Table 1: Hydrogeologic complexes characteristics

\begin{tabular}{lllll}
\hline Complex & Lithotypes & Permeability degree & Permeability type & Hydrogeologic role \\
\hline Fluvial complex & $\begin{array}{l}\text { Alluvial deposits, coarse, medium, fine grained } \\
\text { materials; clay lens }\end{array}$ & Medium-high & Porosity & Water table aquifer \\
$\begin{array}{l}\text { Clay-silt Lake } \\
\text { complex }\end{array}$ & Clay, silt, locally sandy layer and lens & Impermeable & $/$ & $\begin{array}{l}\text { Impermeable } \\
\text { confining layer } \\
\text { Morainic complex }\end{array}$ \\
$\begin{array}{llll}\text { Gliocene complex aquifer } \\
\text { Bedrock }\end{array}$ & $\begin{array}{l}\text { Sand, gravel in silt-sandy matrix, conglomerate } \\
\text { Plutonic igneous rocks }\end{array}$ & Medium & Porosity & Deep confined aquifer \\
Low/impermeable & Fractured & Local aquifer reservoirs \\
\hline
\end{tabular}

Under the lacustrine formation, there is the Pliocene complex, with a heterogeneous lithology, of which there is little information. Its roof is placed at 140-150 m.s.l.m. and its existence is justified by the presence of Pliocene deposits in the right end part of the Amphitheatre.

In the Northern area the lacustrine substrate corresponds to the Alpine rocky basement. Some small aquifers are contained in the areas characterized by a larger number of discontinuities which favor ground water flow.

The hydrogeologic characteristics of the underlying strata are shown in Table 1.

Groundwater flow in the unconfined aquifer: A lot of piezometric level measurements have been made, in order to build the ground water flow pattern. In addition to wells, many superficial water levels (lakes, river) have been considered to trace with more precision the flow net and, particularly, to identify the hydraulic relation between the aquifer and the Dora Baltea river. A passive drainage has been detected; the principal groundwater flow direction is East-West, except in the inner plain area closed between morainic hills, where their morphology causes the flow lines to take other directions.

Groundwater flow is generally directed from the morainic hills to the Dora Baltea River. This fact, together with the geochemistry analysis, allows to conjecture a relation between morainic ground waters and water table aquifer contained in the alluvial materials in the plain.

A particular case has been discovered along the axe Bollengo-Albiano, where piezometric levels have identified a special characteristic of the flow net. An underground watershed separates two flow directions: One towards the Dora Baltea River and the other one towards Viverone Lake, which drains the plain area between the frontal moraine arch and the left moraine, Serra (Fig. 2).

Groundwater depth values are in average inferior to $4 \mathrm{~m}$, with minimum of $1 \mathrm{~m}$ and maximum of about 9 $10 \mathrm{~m}$. These values are one of the major causes of a high vulnerability degree of the unconfined aquifer.

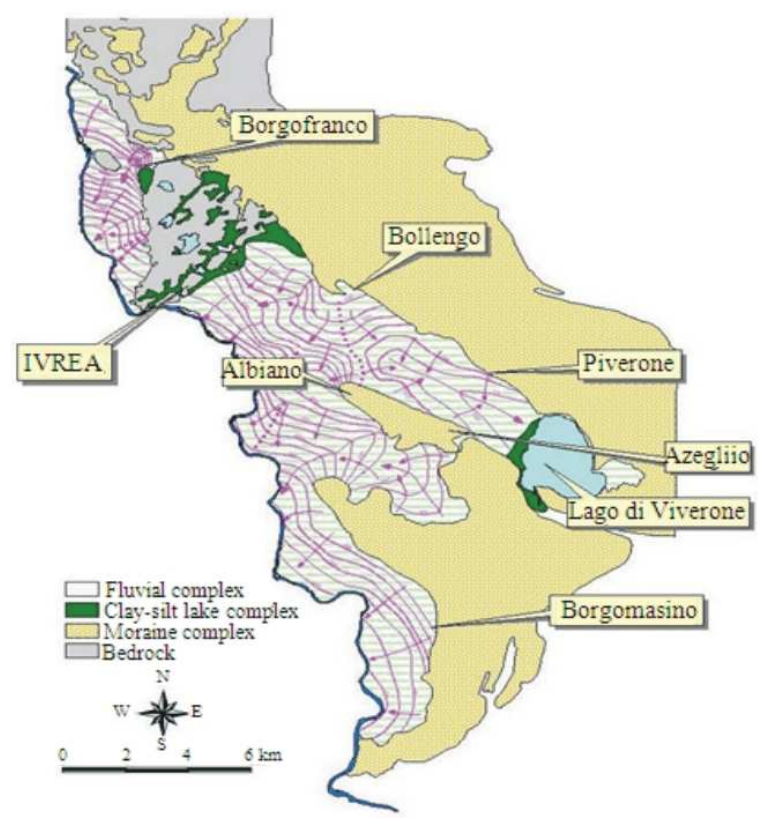

Fig. 2: Hydrogeologic map

Piezometric level oscillation registered during the measurements has been limited to around $10 \mathrm{~cm}$, in order to justify the correlation between different measures, given the impossibility to provide an "instantaneous" image of the water table level.

Aquifers hydrochemistry: Geochemical analysis of many water samples has allowed clarifying many aspects of the existing aquifers in the area under study.

The suspected unconfined aquifer quality degradation is confirmed: high nitrates and sulphates concentrations testify a strong pollution degree caused primarily by agriculture activities (maize cultivation is widely diffused in the area).

Nevertheless, limited areas with good water quality characteristics exist in the northern plain, along the Dora Baltea River and in a limited area near Albiano. This is possible due to less human interference on the territory and thinner grain materials in the unsaturated zone, which provide a better protection of the aquifer. 
The confined deep aquifer presents a very different scenario, because of the protection offered by the confining impermeable lacustrine layer. Here nitrate levels in the water are below the measurement detection level of the instruments. On the other end metal concentrations are higher, as it usually happens for deep underground waters. These characteristics make this deep aquifer water sources suitable for generating drinking water, provided necessary treatments to reduce iron and manganese concentrations are applied.

Morainic springs waters, widely used to provide drinking water, have very good quality and almost all sources belong to the A1A2 class (Fig. 3. Water classification for potable use CNR-IRSA ${ }^{[1]}$ ). Preservation of these precious sources needs to be ensured to avoid a degradation of their quality.

Geochemistry of samples collected from the unconfined aquifer and from the morainic aquifers has highlighted a connection between the underground flows, in accordance with the piezometric network model that has been built.

In particular, the principal hydrogeochemical facies characterizing springs waters is always bicarbonatecalcium based; likewise in the unconfined aquifer water samples the same chemical elements are the dominant factors.

Processes which characterize underground water flows, as dilution and dispersion, are also observed as parameters concentrations change from the foot of morainic hills to the Dora Baltea River, in the direction indicated by the flow lines.

Combined approach SINTACS-GNDCI-CNR basic method: This method has been used, as in the hilly area it has not been possible to apply the SINTACS ${ }^{[2,3]}$ parametric method due to limited data to describe the terrain. No piezometric measures could be referred to an exact aquifer reservoir, as in morainic area underground structure data are limited and not very useful given the chaotic geologic nature of these deposits.

Therefore a unified legend and symbols defined for each hydro-geologic Italian setting (GNDCI-CNR basic method $^{[4,5]}$ ) have been used to assign the vulnerability degree to the complexes in hilly areas (Fig. 4).

With this approach a global view has been obtained: there are two very different scenarios, each one corresponding to distinct geomorphologic and hydro-geologic structures.

Plain area: SINTACS According to the methodology (SINTACS R5) a discrete grid, characterized by $50 \mathrm{~m}$ per $50 \mathrm{~m}^{2}$ cells, has been overlaid on top of the alluvial plain of Dora Baltea River.

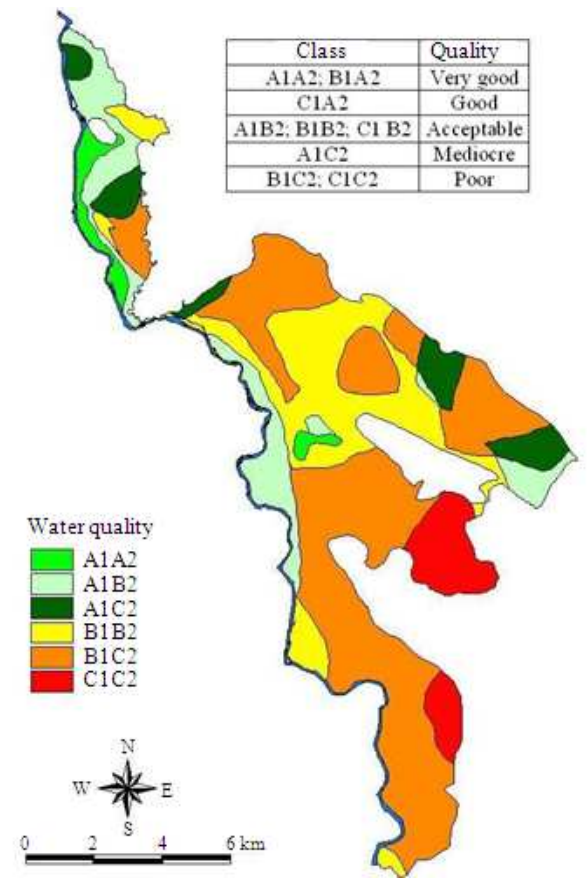

Fig. 3: Groundwater quality of the unconfined aquifer map

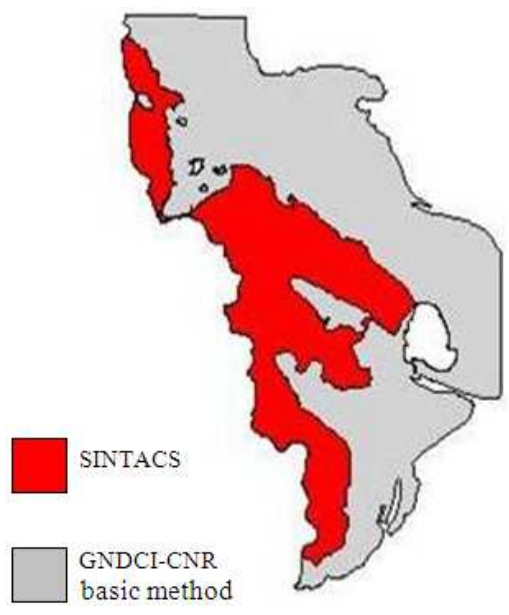

Fig. 4: Subdivision in zones

For each cell the SINTACS index is calculated. This is function of the rating given to the seven parameters considered in the method and of their weights, chosen according to the impact scenario setting for each cell.

A shapefile represents in a Geographic Informatic System GIS-ArcView format every rating parameter. After the grid is overlaid the SINTACS index is calculated as the product of the $\mathrm{P}_{\mathrm{i}}$ rate and the correspondent weight $\mathrm{W}_{\mathrm{i}}$ for the $\mathrm{i}$-th cell: 
Am. J. Environ. Sci., 5 (4): 578-587, 2009

$$
\mathrm{I}_{\text {SINTACS }}=\sum_{\mathrm{i}=1}^{7} \mathrm{P}_{\mathrm{i}} \mathrm{W}_{\mathrm{i}}
$$

The seven parameters have the following characteristics:

Depth to groundwater: Vulnerability degree increases when this parameter decreases, since a water table next to topographic surface reduces considerably mitigation and self-depuration effects of the soil and the unsaturated zone in presence of pollutant elements dissolved in the infiltration water. Therefore SINTACS rating decreases as depth to groundwater increases, following a hyperbolic curve as proposed in SINTACS R5.

Piezometric level values have been measured in June-July 2004 and are characterized by a depth inferior to $3 \mathrm{~m}$ in the South area and a maximum superior to $9 \mathrm{~m}$ in a single well at the border between Ivrea and Cascinette (Table 2).

To the superficial water bodies connected to the groundwater flow, a rating of 10 has been assigned, as they are elements that can cause direct and fast contaminant dispersion in the aquifer system.

Infiltration: This quantity has been calculated by means of inverse hydrologic balance, through computation of precipitation, temperature and evaporation-transpiration, using meteorological data for the area under study.

Only two meteorological stations have been considered. Other stations, although not very far and still belonging to the Dora Baltea river hydro-basin, are characterized by special climatic conditions considered unsuitable for describing precipitation rate and temperature variations in the plain area.

Variation of precipitation $\mathrm{P}$ and temperature $\mathrm{T}$ as a function of the altitude have been computed using least square regression equations. Evaporation-transpiration ER has been computed trough Turc's formula. Then the effective precipitation has been determined as:

$$
\mathrm{Q}=\mathrm{P}-\mathrm{ER}
$$

The effective infiltration I is derived from Eq. 2 and 3 , in case of soil absence or not thick or in case of soil thicker than $1 \mathrm{~m}$ respectively:

$$
\begin{aligned}
& \mathrm{I}=\mathrm{Q} \cdot \chi_{\mathrm{R}} \\
& \mathrm{I}=\mathrm{P} \cdot \chi_{\mathrm{S}}
\end{aligned}
$$

Outcrop complex is alluvial and it has been divided in two sub-complexes to assign infiltration coefficient $\chi_{R}$, as shown in Table 3 .
Table 2: Depth to groundwater rating

\begin{tabular}{ll}
\hline Depth to groundwater $(\mathrm{m})$ & Rating \\
\hline$>8$ & 5 \\
$6-8$ & 6 \\
$4-6$ & 7 \\
$3-4$ & 8 \\
$<3$ & 9
\end{tabular}

Table 3: Infiltration coefficients (overburden $<1 \mathrm{~m}$ )

\begin{tabular}{ll}
\hline Outcrop Complex & $\chi_{\mathrm{R}}$ \\
\hline Medium-coarse alluvium & 0.65 \\
Medium-fine alluvium & 0.45 \\
Lakes & 1.00 \\
\hline
\end{tabular}

Table 4: Soil infiltration coefficient

\begin{tabular}{ll}
\hline Soil & $\chi_{\mathrm{S}}$ \\
\hline Silt-clay soil & 0.10 \\
Sand-clay soil & 0.25 \\
\hline
\end{tabular}

Areas occupied by hydric superficial bodies have a unity coefficient. Areas covered by thick soil have $\chi$ in relation to its texture, as shown in Table 4. Urban areas have been considered as reduced infiltration areas, because of the presence of impermeable surfaces. Therefore in these areas $\chi$ has been diminished with respect to the coefficient that should have characterized the area.

Ratings assigned to infiltration vary between 5 and 9, with minimum in the South extremity of the study area and maximum values in the North plain area, near the Borgofranco village.

Unsaturated zone attenuation capacity: Together with the soil, the unsaturated zone plays a key role like a "defense line" against fluids or hydro-vectored contaminants. In the vadose zone contaminants vertical leakage and their attenuation process take place, until the infiltration fluid reaches the water table.

This quantity represents lithologic description of the unsaturated zone and it is calculated trough a weighted average based on the lithologic thickness data that characterizes the area.

With a certain approximation due to the lack of data, areas lithologicly homogenous have been individuated and a rating has been assigned.

Rating values vary between 4 and 8 . The smallest rating is used if sand is prevalent, or if there are some clay lens or silt structures which provide for a reduction of the vulnerability. This happens in the East area, where there are dominant sand-silt matrices and it is also possible to find clay in the superficial levels. For 
instance, this is the case near the village of Albiano, at the base of the morainic hills.

Ratings of 7 and 8 (in presence of gravel and coarse sand only) apply to the strip along the Dora Baltea River, except in the South area where fine grained materials are again dominant.

Lithologic composition of the vadose zone is strictly linked to fluvial dynamics, since transported and deposited materials depend on the energy and on the transport capacity of the river.

Overburden attenuation capacity: The overburden is the first physical defense line of the hydro-geologic system. Its chemical and physic characteristics influence contaminant percolation.

IPLA maps (National institute for wood plants and environment) and wells stratigraphic data provided basic information to analyze the terrain and to individuate areas covered by overburden (with a thickness of at least $1 \mathrm{~m})$ and areas lacking its presence.

In the IPLA thematic maps different soil classes are presented, according to the Land Capability Classification of Soil Conservation Service adapted to Piemonte territory. This document shows that alluvial soil is prevalent. Only some small areas are instead characterized by a peat soil with silt-clay texture and by a recent alluvial soil in the northern alpine valley area. However their thickness is inferior to $1 \mathrm{~m}$ and therefore these soil types have not been considered.

Urban areas, where impermeable surfaces are more diffuse, are distinguished by a unitary rating (infiltration is reduced as if there would be a clay texture soil). Areas without soil, on the contrary, have maximum rating. Intermediate values between 3 and 8 correspond to silt-clay soil, sand-silt soil, sand soil and soil with vegetables materials.

Hydro-geologic characteristics of the aquifer: Similarly to the unsaturated zone attenuation capacity, a weighted average of the lithologic thickness in the saturated zone describes this quantity. The hydrogeologic characteristics of the aquifer, being either porous medium, fractured or karst, are fundamental to determine the groundwater flow and consequently contaminant dispersion through it.

This study deals with porous medium, constituted particularly by gravel and sand. For coarse alluvial deposits ratings vary between 8 and 9 . For medium-fine material ratings vary in the range of values is $6-8$. In presence of silt or clay ratings decrease up to 3. Rating of 10 has been assigned to lake areas.

Hydraulic conductivity: This is the k parameter in the Darcy's law. It represents the proportional constant between the flow in laminar regimen through an aquifer section and the existing hydraulic gradient. This parameter depends on both the aquifer medium and the permeating fluid and it gives a measure of the absolute permeability of the aquifer. Hydraulic conductivity can be obtained by means of well pumping tests.

In this study this parameter has been characterized by using information found in the literature and by applying the program QSPEC. Moreover SINTACS R5 provides guidelines to choose $\mathrm{k}$ according to aquifer lithology and this method has been used to verify the correctness of the estimate previously determined.

Values between $10^{-3}$ and $10^{-5} \mathrm{~m} \mathrm{sec}^{-1}$ have been determined. Ratings from 5-9 have been assigned, by using the graph described in SINTACS R $5^{[2]}$.

Hydrologic characteristics of the topographic slope: Using the Terrain Elevation Digital Model (DEM) the shapefile providing the slope information has been obtained in an automated way using the Arcview Spatial Analyst environment.

A high slope causes a bigger surface runoff, for a given precipitation rate and, in this case, infiltration and contamination are reduced. On the contrary, limited slopes, as in the case under study, cause pollutants to be less displaced under gravity action.

The downward gravity movement will bring the pollutant through the vadose zone until the water table. At this point it can penetrate in the aquifer and subject to convection transport, to diffusion, dispersion and dilution phenomena, with different characteristics depending to the aquifer medium and the solute type.

As a result the rating is 10 almost everywhere, given that a plain morphology is symbol of high vulnerability to contamination. Only small areas near the morainic hills have an accentuated slope and a lower rating.

In order to calculate the SINTACS index with the (1), the weight strings associated with the scenarios of the area have been chosen:

- Seepage: To delimit this area, where there is a strict connection between the surface stream 
network and the groundwater flow, the Dora Baltea Piano Stralcio Fasce Fluviali (PSFF) has been used. Particularly the seepage scenario area corresponds to band A in the PSFF, which is the area interested by ordinary and recurring flooding.

- Normal impact: This scenario includes the uncultivated lands, the areas where cultivation does not require a heavy use of chemical manures and more generally all the areas without or limited human intervention. Sometimes there are some farming activities, but they are of small dimensions and therefore considered unable to have a severe impact. All the areas occupied by poplars, well identified in the Technical Regional Map (CTR) have been analyzed with this scenario string

- Severe impact: This scenario corresponds to the industrial and urbanized areas, where there may be a lot of actual and/or potential danger centers. In this scenario there are also areas with intensive cultivation, mainly wheat and corn. Also superficial water bodies are also included in this category, since they are elements that can easily transmit pollution in the aquifer

Parametric maps obtained are shown in Fig. 5.

GNDCI-CNR basic method: According to the hydrogeologic complexes, vulnerability has been assessed by means of the unified legend and symbols defined by this HCS (hydro-geologic complex and setting assessment) method, based on homogeneous area zoning $^{[6,7]}$. It includes standard hydro-geologic settings that can be found in the Italian territory.

This method has permitted to build a vulnerability map for the case in which data necessary to apply a parametric method like SINTACS are not available.

It has been used to assess vulnerability of the morainic complex, the lacustrine complex and the bedrock, based on their hydro-geologic behavior.

Bedrock has been analyzed as aquifer in normal fissured plutonic igneous rocks, to which it corresponds a low vulnerability degree.

A low vulnerability degree has also been assigned to the moraine complex, whose structural complexity is characterized by coarse materials as well as by fine grained materials (with low-medium relative permeability). Moreover the absence of towns and agricultural activities, the presence of spontaneous vegetation, are signs of a reduced human impact. Furthermore, in moraines higher depth to groundwater, as compared to the plain, contributes to a low vulnerability.
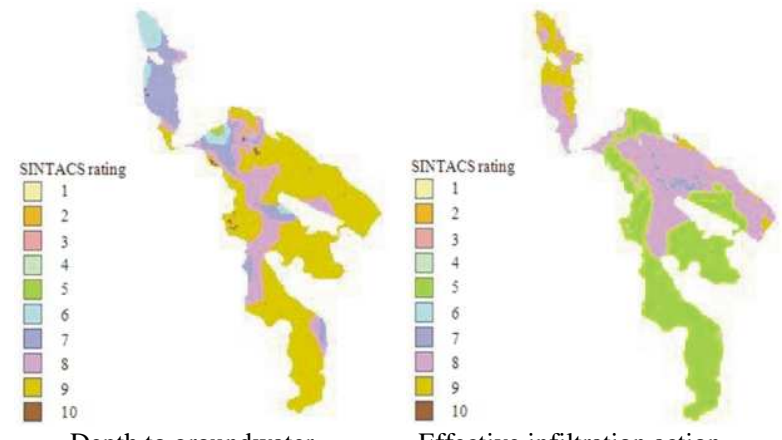

Depth to groundwater
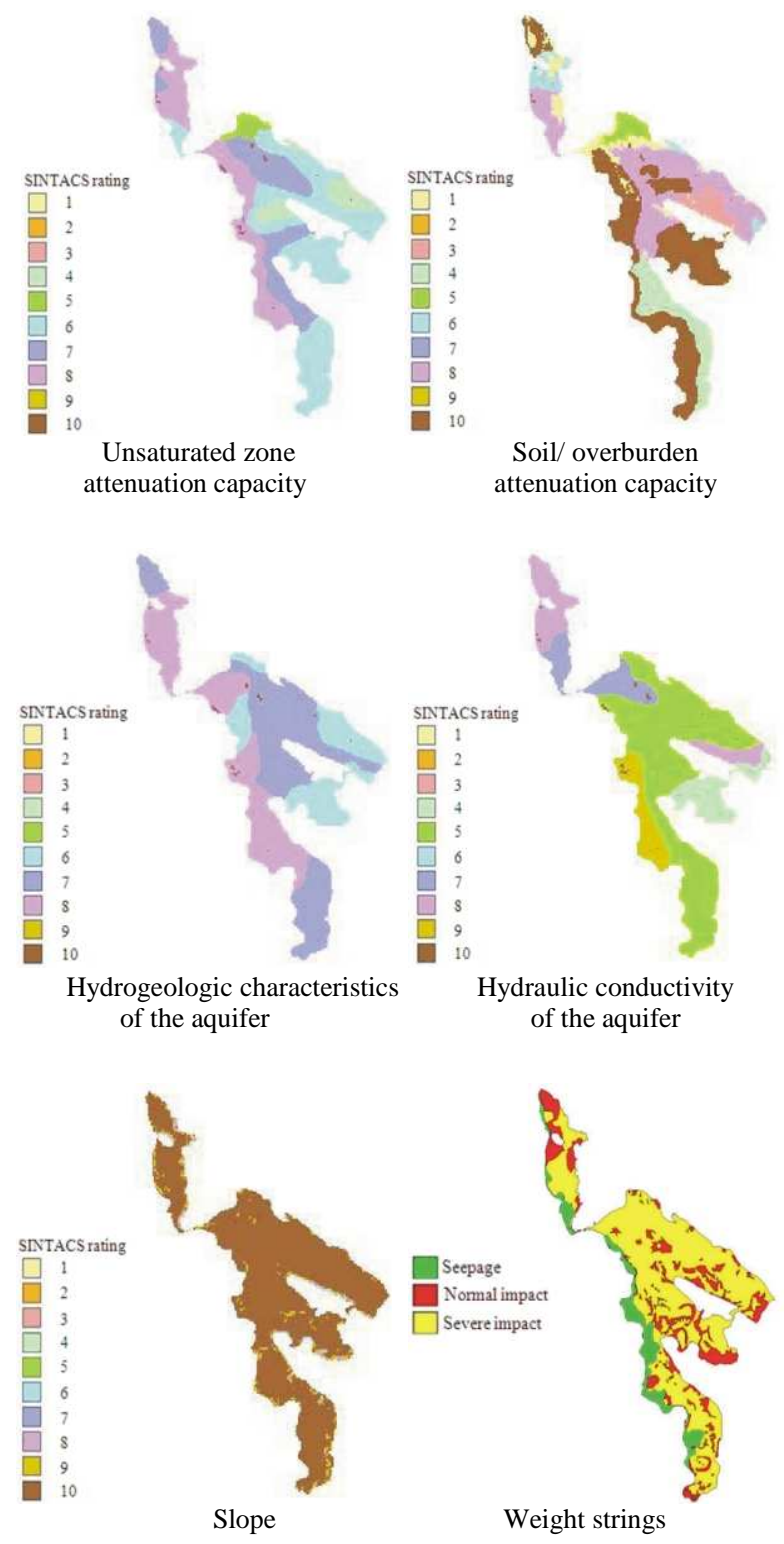

Fig. 5: SINTACS parametric maps 


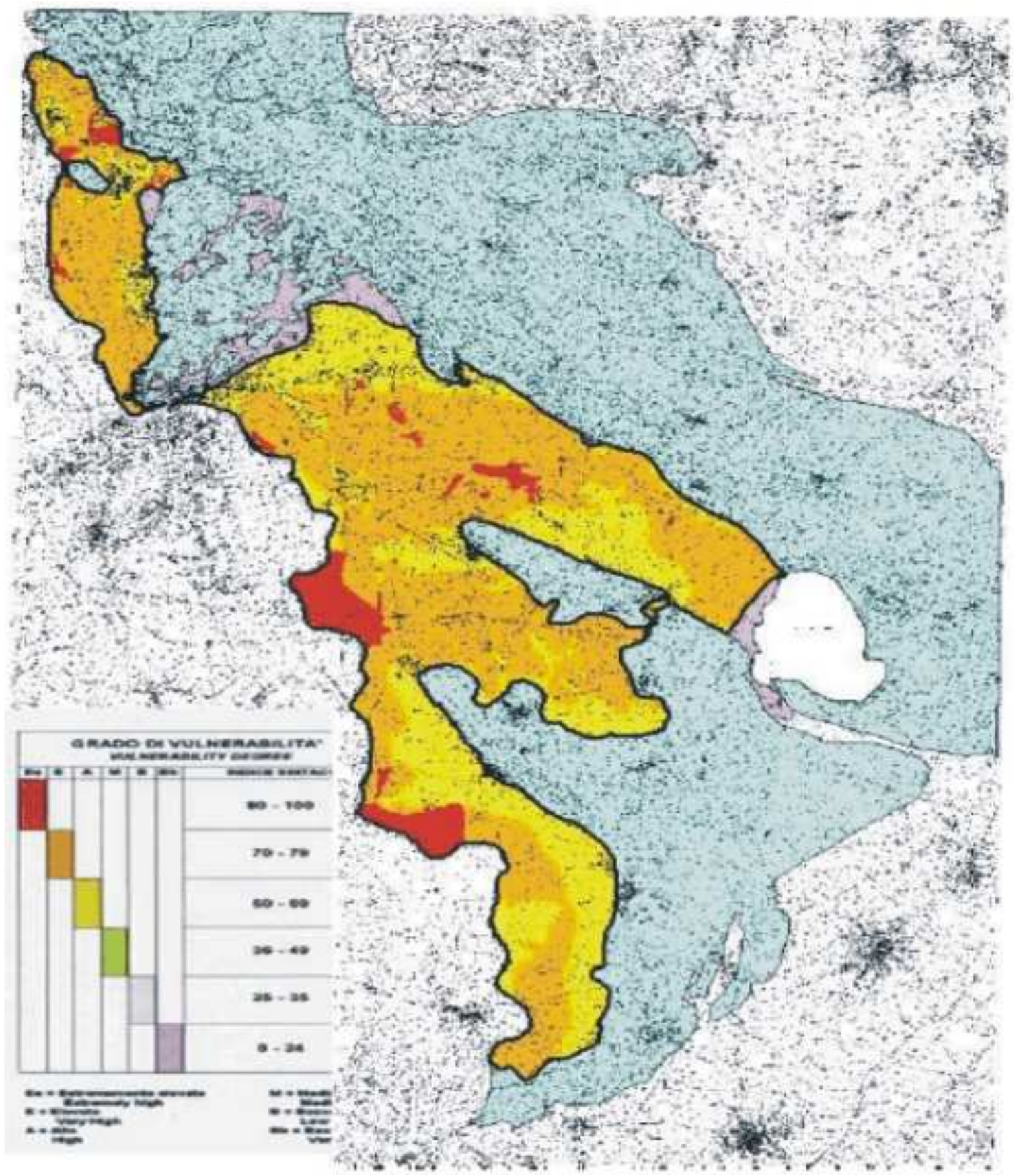

Fig. 6: Intrinsic vulnerability map

Without any doubt clay, silt, peat materials in the North area and near Viverone Lake are characterized by a very low or null vulnerability.

Intrinsic vulnerability map: The map obtained points out the existence of two settings, corresponding to different geomorphological structures and different degrees of human presence in the territory (Fig. 6):

- Hilly area has a low degree of vulnerability

- Plain area has a high degree of vulnerability 
In the plain the depth to groundwater is only a few meters and coarse size grain sediments in the unsaturated zone makes the contamination process very easy. Moreover the presence of many sources of contamination danger deriving from human activities with potentially severe impact on the territory, contribute to yield a high vulnerability.

Overall the quality of the water table aquifer is rather poor, except in limited areas where, actually, there are wells to withdraw drinking water. To preserve water quality in these areas, all the activities that could interfere with groundwater must be accurately controlled. On the contrary, aquifers in morainic deposits, whose many springs are exploited, are more protected: Although heterogeneous, the presence of a fine matrix contributes to a strong permeability reduction and therefore it provides some protection to the aquifers lying underneath, thus reducing contaminant infiltration.

Moreover in the hilly area human presence is limited, so there are no real or potential contamination danger points. In this context these areas and their springs must be absolutely preserved.

\section{RESULTS AND DISCUSSION}

Vulnerability assessment, which represents the conclusion of this hydro-geologic study, shows a critic situation in the plain area, where vulnerability degree goes from high to very high, mainly because of the reduced depth to groundwater. This structure is the principal cause of an easy contaminant percolation to the saturated zone of the aquifer system.

Concerning the application of the BASIC Method Gndci-Cnr, the vulnerability degree is between low and very low for morainic, lacustrine and bedrock complexes. These areas, especially where there are springs exploited by the communal aqueducts, must be preserved, avoiding a heavy human intervention on the territory.

\section{CONCLUSION}

The main recommendations, based on the results of this hydro-geologic study, are summarized in the following:

- Verify the presence of potential contamination danger points, particularly in the high vulnerability areas, where they could easily become a source of contamination for the aquifer. New groundwater drinking resources must be searched in low vulnerability areas

- It is preferable, in high vulnerability zones, to draw water from deep confined aquifer and to secure that there would not be a connection with the water table aquifer, by means of careful cementation, providing walls of an impermeable element that separate deep aquifer from water table one

- Control respect areas for wells and springs

- Pay attention to the real contamination danger points, which can constitute a pollution source, especially in high vulnerability areas. Also, superficial water bodies must be controlled, as they are able to convey pollution elements in the aquifer

- $\quad$ Preserve deep groundwater resource for drinking water purposes

- Favorite formation of aqueducts between towns, to allow a better management of groundwater resources and their preservation

- Enhance depuration structures and avoid dumping in surface water bodies connected with the water table aquifer

- Continue to focus on protection of groundwater in morainic areas, through careful control and adequate planning

\section{REFERENCES}

1. Civita M., A. Dal Pra, V. Francani, G. Giuliano and G. Olivero et al., 1993. Proposta di classificazione sintetica e mappatura di base della qualità delle acque sotterranee. Inquinamento $\mathrm{n}$, 12: 8-17.

2. Civita M.-de Maio M., 2000. SINTACS R5Valutazione e cartografia automatica della vulnerabilità degli acquiferi all'inquinamento con il sistema parametrico-Pitagora Editrice Bologna.

3. Civita M.-de Maio M., 2002. La Carta di vulnerabilità degli acquiferi del settore di RivoliAvigliana (Piemonte, Italia): applicazione dell'"approccio combinato"-Estratto da IGEA $\mathrm{N}^{\circ}$ $17 / 2002$.

4. Civita M., M. de Maio, M. Farina and A. Zavatti, 2001. Linee-guida per la redazione e l'uso delle Carte della vulnerabilità degli acquiferi all'inquinamento. Manuali e linee-guida dell'ANPA, 4/2001, 99 pp., 1 CD-ROM.

5. Civita M. and M. de Maio, 2002. Atlante delle Carte di vulnerabilità delle Regioni italiane. DBMAP, Firenze, pp: 369. 
6. Civita M. and M. de Maio, 2003. Assessing and mapping groundwater vulnerability to contamination: The Italian "combined" approach. Proceeding of the 1st International Workshop on Aquifer Vulnerability and Risk, May 20-30, Salamanca, Mexico, pp: 3-19.
7. Civita M. and M. de Maio, 2004. Assessing and mapping ground water vulnerability to contamination-the Iitalian "combined" approach. Geofisica Int. 43: 4-19. 